\title{
BCL2A1 wt Allele
}

National Cancer Institute

\section{Source}

National Cancer Institute. BCL2A1 wt Allele. NCI Thesaurus. Code C104039.

Human BCL2A1 wild-type allele is located in the vicinity of $15 q 24.3$ and is approximately $14 \mathrm{~kb}$ in length. This allele, which encodes $\mathrm{Bcl}$-2-related protein $\mathrm{A} 1$, is involved in the down-regulation of apoptosis and mediation of the inflammatory response. 